\title{
Vietnam's Rice Price at the Intersection of Globalisation and Climate Variability
}

\author{
CAROLINA GAVAGNIN, M. BRUNA ZOLIN \\ AND ANDREA PASTORE
}

\begin{abstract}
Vietnam has made huge economic improvements since the mid-1980s, opening up to international relationships and undergoing important economic and political reforms. It is also listed among the countries most vulnerable to the negative impacts of climate variability, forecasted rising temperatures and more frequent and intense severe climate-related natural disasters (floods, droughts, storms, typhoons, etc.). Rice plays an important role in Vietnam's national food security, rural development and political stability. The aim of this study is to analyze the pattern of domestic rice prices using potential variables from the supply and the demand side. It will focus on the role played by climate variability and severe weather events while also taking into account the strong public support for the sector. With this aim, the researchers have developed a regression model for mapping the domestic rice price through the generalized least squares model.
\end{abstract}

Keywords: rice, Vietnam, price, climate variability, public policies

\section{Introduction}

Vietnam has strengthened its economic integration and international relations since 1995, aware that in order to achieve its economic goals it had to keep its door open to foreign trade and investment. In July 1995, it became a member of the Association of Southeast Asian Nations (ASEAN) and later, in January 2007, a member of the World Trade Organization (WTO). The opening of its borders and the transition to a market economy exposed the country to the effects of globalization, but while some emerging Asian economies are facing concerns about weak domestic demand and reductions in exports, Vietnam is continuing to grow economically.

Vietnam is a medium-sized country. According to The World Factbook $2014,{ }^{1}$ the population is about 93 million, with a density of 271 people/ $\mathrm{km}^{2}$. The median age is $29 .^{2}$ The North is more populated and devoted 
to agriculture, while the South is more advanced and industrialized. While Vietnam is making every effort to increase industrialization, the country still has many rural features: 48 per cent of the total workforce is employed in agriculture and the sector contributes 19 per cent to GDP. ${ }^{3}$ Research from the International Labor Organization (2011) shows that the largest employment sector in Vietnam remains the agriculture, forestry and fisheries sector, with 23 million employees in 2008. ${ }^{4}$ The industrial sector accounts for 21 per cent of the total work force, while the services sector accounts for 31 per cent and the GDP per centages are 38.5 per cent and 42.2 per cent respectively (World Factbook 2014). According to the World Bank (2014) the percentage of people living in rural areas fell from 79.7 per cent in 1990 to 71.2 per cent in $2010 .{ }^{5}$ Rural-to-urban migration is an inevitable outcome of growing industrialization, with the resulting need to produce more food for the urban population.

Agricultural land constitutes 35 per cent of the total surface area and only 20.6 per cent of the total surface area is arable. ${ }^{6}$ Agriculture in the north is concentrated in the lowland areas of the Red River Delta (covering $16,700 \mathrm{~km}^{2}$ ) and along the central coast to the south. The Mekong (covering 40,000 $\mathrm{km}^{2}$ ), is among the great rice-producing regions of the world, and is the predominant agricultural region of the south. These two regions are arable and fertile, separated by mountains and hills, and cover about 20 per cent of the territory (World Factbook 2014).

Vietnam had a centrally planned economy until 1986, when the government approved the Doi Moi reform, which paved the way to a gradual transition to a more competitive economy and boosted economic relationships with several countries. As a trading nation, since 2012 Vietnam has been recording an export growth rate higher than its import growth rate. Currently, the main imported agricultural commodities in Vietnam are soybean cake, wheat, maize, soybeans, palm oil, chicken meat, cotton lint, molasses, malt and meat. The agricultural commodities that are most often exported include rice, dried cassava, green coffee, dry natural rubber, fresh fruit, cashew nuts (shelled), watermelons, coconuts, tea and pepper. Before the reforms introduced in the 1980s, the Vietnamese agricultural system was relatively inefficient, perhaps because it was based on cooperative monopolies and fixed public prices.

At that time, the rice produced domestically did not meet the food needs of the entire population. The most important reform introduced at the end of the 1980s was Decree No. 10 (5th April 1988), in which the family, instead of the cooperative, was recognized as the base unit in agriculture. Even if the government continued to own the land, the 
production output became the property of the farmer and the role of the cooperatives was limited to furnishing services. Some years earlier (1981), another important reform, called the 'output contract system', had been adopted. This reform decreed that farmers, after delivering to the public authorities the agreed production quota, could keep the remainder and sell it on the free market. Through a production group or cooperative, the output contract system allocated plots of land to individual farmers and a production delivery quota for each farmer was established, based on average yield over the previous three years (St John 2006).

Although these reforms boosted the economy, the improvement was below expectations. Thus, the time span of the land concession period was lengthened from five to 15 years and the production quota target fixed by the government was reduced to let the producer put on the free market at least 40 per cent of their production output. In 1993, the Vietnamese government adopted a new Land Law, amended in 1998, 2001 and 2003.7 According to this 'new' law, land belongs to the Vietnamese people but, with the amendments introduced in 2003, the possessor of land use rights is also allowed to exchange, sell, lease, mortgage, inherit, and give them as a gift (Van Suu 2007). However, the price paid by farmers for land leases was regulated by the state based on land prices prevailing in the market. In 2013, the National Assembly adopted the current Land Law that extended land-use rights for agricultural and forestry land from 15 to 50 years. Additionally, it contains more limitations on the government acquiring land, even for the purposes of economic development.

Vietnam has made huge economic improvements since the mid-1980s. However, sustainable development (from the economic, social and environmental points of view) has faced numerous barriers: conflicts in land utilization, the adverse impact of climate change, the growing divide between cities and the countryside, between North and South and between the new emerging affluent classes and the still-poor sections of the population. The opening to the global market has led Vietnam to convert agricultural land to create space for industrialization and urbanization (Van Suu 2009) and, as a consequence, conflicts have increased due to the state and farmers having different priorities with regard to land-use. Since a significant section of society relies on agriculture and natural resources for primary income, climate change has been and will continue to be a critical factor affecting productivity in the region.

Rice is an integral part of Vietnamese life, playing the most important role in food security and rural development. Of all agricultural products, 
rice is indispensable to the daily life of the Vietnamese population. Like bamboo, it is also a significant emblem of rural areas in Vietnam and riceproducing areas attract tourism to their unique natural landscapes. Rice price fluctuations inevitably have serious repercussions in the country.

Starting from these premises, this study aims to analyze the temporal evolution of rice prices in Vietnam using potential covariates, from the supply and the demand side, with a specific focus on the role played by climate variability and severe weather events, and taking into account the strong public support granted to the sector. This section discusses the main features of the climate in Vietnam, the country's vulnerability to the impact of climate variability and future climate projections. Section 2 provides a brief overview of the characteristics of the domestic rice market. Section 3 investigates the main policies undertaken by the Vietnamese government in support of rice prices. Section 4, after a description of the available data sources, presents the results of the statistical analysis. The article concludes with a discussion of the future challenges facing Vietnam in this context.

\section{Climate Variability in Vietnam}

Spanning 15 degrees of latitude, Vietnam hosts different micro-climates throughout its territory: the southern regions, near the equator, have a tropical climate, whereas the northern regions in the humid subtropics have greater seasonal variation (UNEP and IPONRE 2009). ${ }^{8}$ Vietnam's topography is also varied: it ranges from mountains and hills covering 75 per cent of the country, to sedimentary deltas - heavily cultivated and populated fertile plains - which are also the most important ricegrowing areas (UNFCC 2010). ${ }^{9}$

Temperatures in the north range on average from $15-20^{\circ} \mathrm{C}$ in winter to $22-27.5^{\circ} \mathrm{C}$ in summer; in the south, winter temperatures, which range from $26-27^{\circ} \mathrm{C}$, do not differ greatly from the summer season temperatures, which vary from $28-29^{\circ} \mathrm{C}$ (McSweeney et al. 2012)..$^{10}$ Annual rainfall varies between 700-5,000 $\mathrm{mm}$ and northern regions generally receive more precipitation than southern ones (UNEP and IPONRE 2009). The monsoon season generally brings heavy rainfall to both north and south from May to October, and in central regions from September to January.

Inter-annual climatic variations tend to be associated with the El Niño Southern Oscillation (ENSO), ${ }^{11}$ which is believed to influence monsoon behaviour (Loo et al. 2015; Vu et al. 2015), resulting in drier and warmer than average conditions in Southeast Asia during El Niño years (GFDRR 
2011; McSweeney et al. 2012)..$^{12}$ ENSO has long been associated with extreme climate anomalies, including changes in the space-time patterns of floods, droughts, cyclones and/or severe storm activity, cold and/or hot spells etc. (Huang and Hu 2007; Naylor et al. 2007; Rasmusson and Wallace 1983; Roberts et al. 2009; Ropelewski and Halpert 1989; Walker and Sydneysmith 2008). ${ }^{13}$

ENSO is quantified by the Southern Oscillation Index (SOI), a standardized index based on the differences in observed sea level pressures between Tahiti, French Polynesia and Darwin, Australia. ${ }^{14}$ Thus, the SOI measures the large-scale fluctuations in air pressure occurring between the western and eastern tropical Pacific during El Niño and La Niña episodes. Prolonged periods of negative (positive) SOI values coincide with abnormally warm (cold) waters across the eastern tropical Pacific typical of El Niño (La Niña) episodes. In this study, when analyzing the influence of climate variability on the Vietnamese domestic rice price patterns, the Southern Oscillation index will be used.

Given its exposure to floods, droughts and storms, and the fact that its two important economic sectors - industry and agriculture - are located in coastal lowlands and deltas, Vietnam has been listed among the countries that will be worst-affected by the impact of climate change in the Asia-Pacific Region (GFDRR 2011; Kreft and Eckstein 2014). ${ }^{15}$

In Vietnam, the areas projected to suffer from the increased frequency and intensity of these weather extremes are those with already high levels of poverty. These are mainly coastal areas, which are particularly vulnerable to rising sea levels, and thus flooding and salinity. In particular, the Mekong River Delta and the Red River Delta are threatened and they are also the main rice-producing areas in the country.

According to the Intergovernmental Panel on Climate Change (IPCC), global climate models predict the following scenarios for the future climate in Vietnam, with varying magnitude at the regional level (UNEP and IPONRE 2009): mean annual temperatures are projected to increase by $1^{\circ} \mathrm{C}$ to $2^{\circ} \mathrm{C}$ by 2050 , leading to an increase in the number of heat waves and a decline in cold surges; annual and seasonal rainfall are projected to increase (with the exception of autumn rainfall), the proportion of precipitation during severe weather events is projected to increase by 2090 (McSweeney et al. 2012), along with the probability of extreme rainfall and flooding; the sea level is projected to rise by 2050; with sea surface temperature increases, tropical cyclones will become more intense.

Adaptation measures - including flood and water management structural improvements - need to be developed and implemented in order 
to minimize the negative impact of climate change, especially of rising sea levels. Farmers will face increased risks; therefore, they will need improved farming knowledge and more flexible and diversified farming systems (Badiani et al. 2013). ${ }^{16}$ Over the last few years, the Vietnamese government has recognized the benefits of responding to climate change and has embraced efforts to prioritize this theme in its legal framework and policy development (UNDP 2015; World Bank 2011). ${ }^{17}$

\section{The Rice Sector}

In Vietnam, rice plays an important role in national food security and political stability. Rice also has a direct effect on social security because it is the staple food for more than 95 per cent of the population and an important source of income for more than 60 million people living in agricultural and rural areas (Hai 2012).${ }^{18}$ Rice is the country's main crop, accounting for more than 90 per cent of total cereal production. Vietnam is the world's fifth largest rice-producing country and the second largest rice exporter after Thailand (Cosslett and Cosslett 2014).

There are three annual cropping seasons (Table 1): the winter-spring or early season, the autumn or mid-season and the main long-duration wet-season crop. The Mekong Delta, the largest rice-producing area, is cropped during the autumn season (Maclean et al. 2013). ${ }^{19}$ In recent times, the winter-spring rice crop has become the main crop of the year, as it is usually more productive than the summer-autumn crop. Its productivity is sensitive to temperature variations. Depending on the climatic zone, the yield is lower in years with higher-than-normal air temperatures in the mid-winter period (from December to February) than when the mean temperature is below average.

Most of Vietnam's rice is produced in the Mekong River Delta region (Maclean et al. 2013); other rice-growing regions are the Red River Delta, the northeast, and the north-central coast. The following table summarizes the three main cropping seasons, distinguishing the two phases of crop planting and of crop harvesting.

TABLE 1. Rice Production Seasons

\begin{tabular}{|l|c|c|}
\hline & Planting & Harvesting \\
\hline Main & May-Aug & Sep-Dec \\
\hline Winter-Spring & Dec-Feb & Apr-Jun \\
\hline Summer-Autumn & Apr-Jun & Aug-Sep \\
\hline
\end{tabular}

Source: http://ricepedia.org/vietnam 
According to United States Department of Agriculture (USDA) data, ${ }^{20}$ since 1960 rice $^{21}$ production has continuously increased, particularly from the early 1980s: as is shown in Figure 1, since the mid-1980s production (solid line) has almost quadrupled, reaching 45 million metric tons in 2014. Such an increase may be explained by the expansion of the harvested area and rising yields. The total rice cultivated area (longdashed line) has expanded, though with a decreasing growth rate: 5,468 hectares of land were dedicated to rice planting in 1980, and this was gradually increased to 7,700 hectares in 2014. Rice yields (dotted line) improved from 2.17 MT/ ha in 1980 to 5.84 MT/ha in 2014: higher yields are attributable to the use of input-responsive modern varieties, sufficient fertilizer and an increase in the proportion of rice areas under irrigation (Maclean et al. 2013). Rice farms are generally small-sized: only 2 per cent of rice farms throughout the country cover more than 2 hectares land and 47 per cent of farms are smaller than 0.2 hectares. In the Mekong Delta Region, the average size of rice farms increases slightly, with only 8 per cent of farms smaller than 0.2 hectares and 14 per cent of farms larger than 2 hectares.

FIGURE 1. Rice Domestic Market: Production, Consumption, Harvested Area and Yield, 1960-2014*

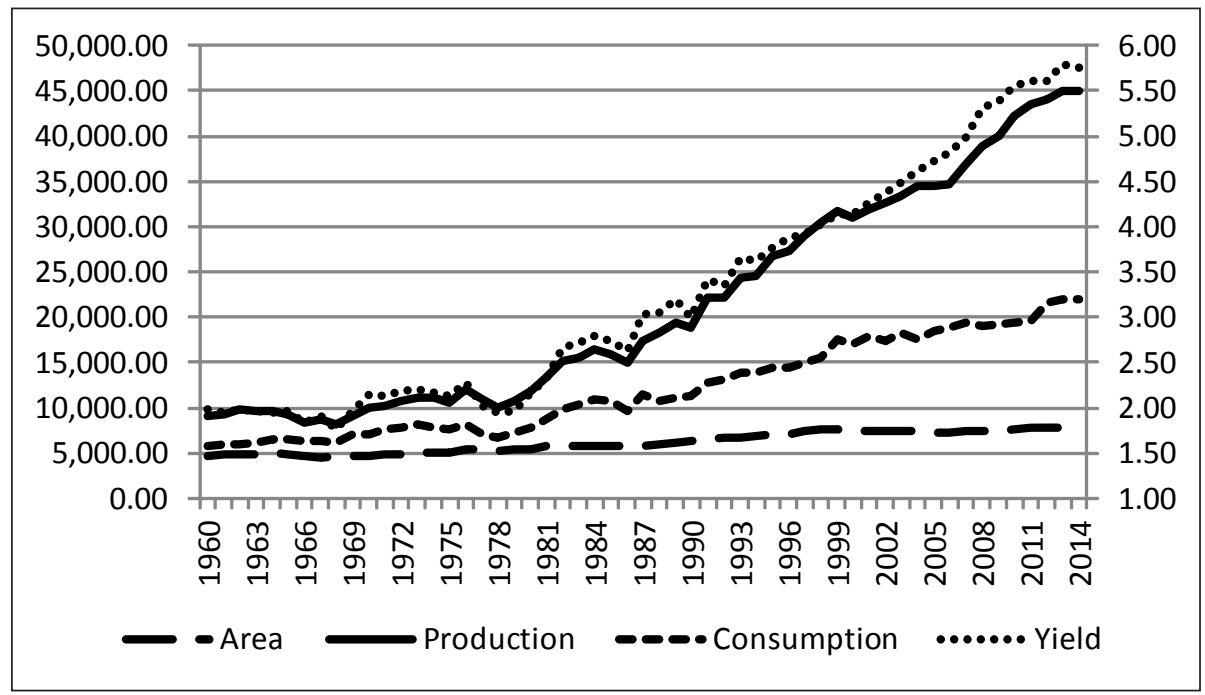

*Production, consumption and harvested area on the left y-axis, values for yields in the right yaxis. Production refers to rough (unprocessed) rice production.

Source: Authors' elaboration based on the United States Department of Agriculture (USDA) data.

Domestic rice consumption in Vietnam (dashed line) has been steadily increasing, but at a slower pace. Per capita consumption has shown an increasing trend since the mid-1970s. Since 2012, after experiencing a 
sudden peak, it has started a slight decline. Indeed, population growth contrasts with a change in dietary preferences, and declining per capita rice consumption is due to an increase in the consumption of other dietary sources such as meat and wheat.

Vietnam has also changed from being a net rice importer to being a net rice exporter. Between 1989 and 2012 rice exports from Vietnam rapidly increased (moving from 1,670 to 6,700 thousand MT), and the country became the second largest exporter in the world after Thailand (VIETRADE 2013). ${ }^{22}$ In 2014, exported rice accounted for around 15 per cent of total annual rice output.

\section{Public Price Support}

Vietnam has adopted a range of public policies in the rice sector over the past few decades. Many Asian countries where rice production is most concentrated - Vietnam included - maintain strict public policies and restrictions on rice imports and exports in order to achieve domestic food security and to protect producer prices and incomes, thereby causing major distortions in trade. Our interest is particularly focused on public interventions affecting rice prices. To stabilize rice prices, the Vietnamese government has introduced measures such as adjusting supply and demand by buying or selling rice to control the national inventory, and by prescribing price brackets (maximum or minimum). The price subsidy is less damaging to the rice market, although the government can still stipulate maximum and minimum prices for most agricultural inputs and products.

The Ministry of Agriculture and Rural Development (MARD), the Ministry of Industry and Trade (MOIT) and the Vietnam Food Association (VFA) are key actors in the Vietnamese rice industry. MARD and MOIT are normally responsible for overseeing the rice industry and providing forecasts on prices, supply and demand (Ngan et al. 2010). ${ }^{23}$ However, they intervened directly in 2008 during the global food crisis, banning rice exports from March to June 2008 with the aim of ensuring domestic food security. Another relevant body is the VFA, an organization comprised of enterprises involved in agricultural commodities production, processing and trade. It is also authorized to issue regulations on the implementation of export contracts and is responsible for setting a floor price on export contracts (Dawe 2010). ${ }^{24}$ In addition, two state-owned enterprises - the Northern Food Corporation (Vinafood I) and the Southern Food Corporation (Vinafood II) - play key roles in the marketing of rice. 
In 1981, Vietnam switched from a collective agricultural production system to an individual-oriented contract system (Denning and Tòng Xuân Võ 1994): ${ }^{25}$ rice farmers were responsible for fulfilling their own production quotas; the contracted output quota was sold to the state at a fixed price, whereas the above-quota surplus could be sold on the free market (Ghosh and Whalley 2004). During 1981-1986, rice production increased sharply, mainly due to increasing yields.

Since 1988, market liberalization has been implemented through the Doi Moi (meaning 'renovation') policy: the private ownership of farm assets was legalized and cooperative land was allocated to individual farmers (Xie and Napasintuwong 2014). In the 1990s, rice production and exports had a boost: production increased by 4.4 per cent per year during 1987-2011 and exports increased by 8 per year during 1989-2010 (Pingali and Xuan 1992; Young et al. 2002). ${ }^{26}$

The Vietnamese government has used pricing policies mainly to promote rice production and ensure food security in the domestic market. ${ }^{27}$ On the international market, Vietnam has promoted pricing policies to control or support rice exports and to stabilize domestic prices (Xie and Napasintuwong 2014). Price support measures also aim to support rice farmers' incomes. The pricing method consists of a floor price policy, with enterprises buying rice from farmers at the minimum purchase price. The Ministry of Finance determines the socalled paddy (floor) price. It is based on production costs in order to make rice production profitable for farmers and encourage them to keep paddy land. More specifically, when the market price is equal to or higher than the paddy price, the government does not intervene. When it is lower, the government intervenes to keep the market price higher than the paddy price.

With its commitment to WTO and ASEAN principles, Vietnam has abolished all export quotas and export subsidies. Nevertheless, Vietnam still interposes into rice exports with tariffs when the domestic supplydemand balance is threatened or the domestic rice price is not stable (Cong ${ }^{28}$ Thang and Thi Bao 2015).

In relation to input supervision, variety improvement is an important instrument for increasing rice yields. Vietnam has adopted and promoted hybrid rice and in 2009 the planted area of hybrid rice accounted for 10 per cent of the total planted area (Bo and Buu 2010). The government also continues to invest in irrigation, resulting in an increase in cropping intensification and rice-planted areas: about 95 per cent of rice areas in Vietnam are now irrigated (USDA 2012). ${ }^{29}$ 
Since 2003, Land Law Vietnam has followed a strict policy of reserving a certain proportion of agricultural land explicitly for rice cultivation: in 2009 , the government set itself the goal of reserving 3.8 million hectares solely for rice production by 2020 (Son 2010). In 2012, the government also undertook to pay input costs for farmers on paddy-reclaimed land in the event of natural disasters. Policies such as these were aimed at improving the agricultural input market in terms of price stability and food safety management, and to help reduce the impact of price shocks on farmers' production (Nachmany et al. 2015). ${ }^{30}$

\section{Domestic Price Determinants}

In view of the situation discussed above, we now aim to analyse the behaviour of rice prices in Vietnam and their determinants. Starting from October 2004 the domestic price of rice underwent a series of different phases. Until October 2007, when it passed the 300 USD/MT threshold, the price showed an upward trend. Then, it suddenly and sharply rose, reaching values close to $500 \mathrm{USD} / \mathrm{MT}$, giving rise to a period of strong variability until October 2011, when it exceeded 500 USD/MT and started to show a declining trend, marked by short and frequent oscillations until it approached values close to 300 USD/MT by May 2015 (see Figure 2, below).

FIGURE 2. International and Domestic Price of Rice, USD/MT, October 2004-May 2015

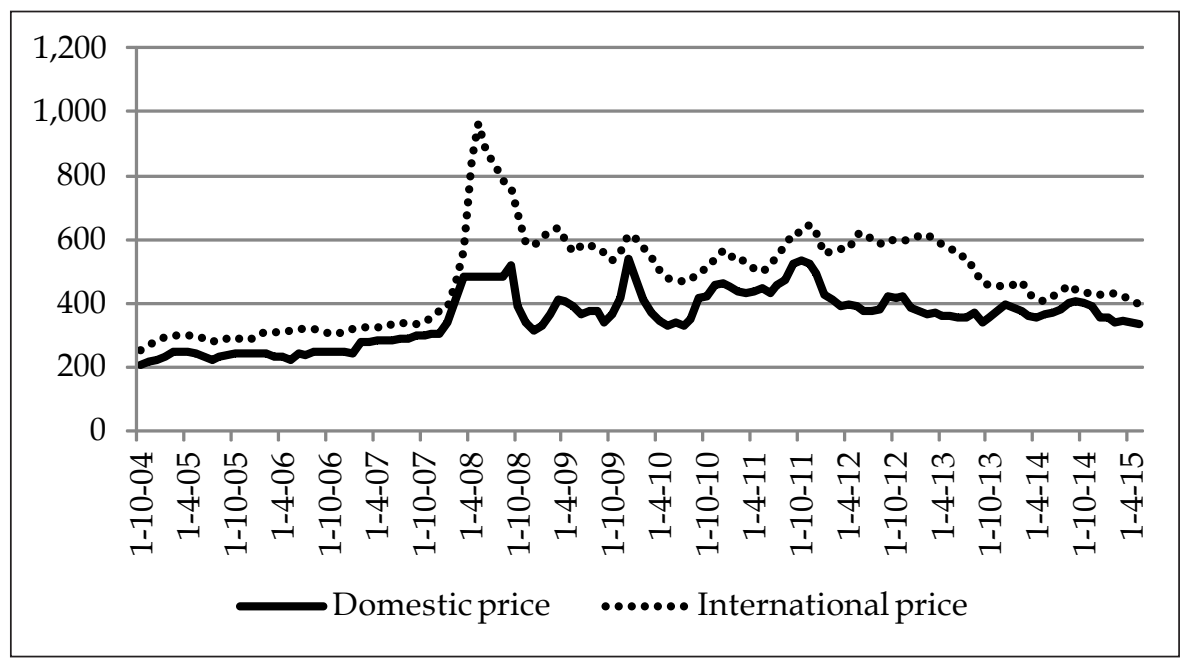

Source: The Thai Rice Exporters Association and the FAO Food Price Monitoring and Analysis Tool (FPMA). 
There are multiple factors that may have affected the domestic rice price, on both the supply and demand sides: the size of the cultivated land and land productivity, the international price of rice, the price of substitute commodities, fuel and fertilizer costs, per capita income, rice stocks, weather conditions and public policies (Childs and Kiawu 2009; OECD 2008; Pandey et al. 2010). ${ }^{31}$

\section{Data}

Data have been collected from official statistical sources, on the basis of their reliability, accuracy, compliance, usability, temporal proximity and, in some cases, comparability. This has influenced some of the explicative variables selected and included in the model. ${ }^{32}$

Due to data availability constraints, only monthly data for the period from October 2004 to May 2015 have been considered for the present analysis. When dealing with yearly series the same value has been repeated for the whole year. When comparing the international and the domestic prices of rice, two different grades of rough rice prices are considered: in this specific case, we consider the prices that are usually reported as benchmark prices (see below). In the regression model, the dependent variable is represented by the domestic rice price in Vietnam. The covariates that have been taken into account as potential explicative variables include: the international price of rice, the Southern Oscillation Index, the world price of maize, the price of fertilizer, the price of oil, the USD/Dong exchange rate, rice ending stocks, GDP, rice harvested area and productivity. (We initially expected a component of seasonality, so we tried to include in the model covariates in order to detect it. We did not eventually find any evidence of seasonal components with regular periodic character, nor specific monthly effects.)

Data referring to the domestic price of rice in Vietnam correspond to the An Giang 25 per cent broken rice wholesale price, expressed in USD/Kg, published by Agroinfo and the FAO Food Price Monitoring and Analysis Tool (FPMA) ${ }^{33}$ on a monthly basis. An Giang is the largest rice-producing province in the Mekong River Delta. USD values for the domestic price have been considered, since commodities market prices are generally expressed in this currency.

The international price of rice is represented by the Bangkok ${ }^{34} 25$ per cent broken rice export price, expressed in USD/tons, provided by the Thai Rice Exporters Association ${ }^{35}$ and the FPMA on a monthly basis. 
It is generally considered as the benchmark price for the international rice trade.

We included variability in the model following a long process, which started with the selection of various databases relating to severe weather events and climate variability. We evaluated these according to data availability, reliability, pertinence and usability and proceeded with several attempts to test whether they could be included and used to estimate the model. Our results showed that the only statistically significant covariate is the Southern Oscillation Index. The Southern Oscillation Index, calculated as the standardised anomaly of the mean sea level pressure difference between Tahiti and Darwin, has been monitored and constantly updated by the Australian Government National Climate Centre - Bureau of Meteorology. ${ }^{36}$ The SOI is computed and made available on a monthly basis; daily or weekly values of the index do not convey much in the way of useful information about the current state of the climate.

The other databases we made use of are:

- Desinventar Disaster Information Management System: a tool providing national disaster inventories, collecting data about the effects of disasters. What interested us the most is that among the collected data, the size of rice harvested area damaged by disasters was indicated. The main disadvantage was that Vietnam's database was updated only until 2010;

- EM-DAT The International Disasters Database: a tool containing data on the occurrence and impacts of disasters in the world starting from 1900. Though it is constantly updated, we chose not to use it as it lacked usability and, in some cases, reliability. Nevertheless, it was used to include episodes of severe weather events as shown in Figure 5.

The International Grains Council ${ }^{37}$ provides a periodic overview of grains markets and, specifically, of monthly maize prices; as a benchmark of the international price of maize the f.o.b. Argentina, Up River maize price is commonly considered.

In relation to the price of fertilizer ${ }^{38}$ and GDP per capita, data have been published by the World Bank World Development Indicators and the Global Economic Monitor databases. ${ }^{39}$

The possible effect of the exchange rate on commodity prices has been addressed in a wide literature (Gilbert 1989; Abbott et al. 2008; Harri et al. 2009; Baffes and Dennis 2013; Arezki et al. 2014; Tulasombat et al. 2015). US Dollar/Vietnamese Dong exchange rate data have been 
obtained from the International Monetary Fund (IMF) database. ${ }^{40}$ The statistical source of reference for rice harvested area and productivity in Vietnam is the FAOSTAT database, whereas the USDA's Production, Supply and Distribution Database ${ }^{41}$ provides data on rice ending stocks in Vietnam. ${ }^{42}$

Concerning public policies implemented by Vietnam in the rice sector, we conducted an in-depth literature-review and data collection process, which allowed us to outline an overall framework of public interventions in the sector, the different public institutions involved and their respective roles (ADB 2012; Nguyen 2015; WTO 2013; Xie and Napasituwong 2014). ${ }^{43}$

We analysed public intervention in the rice sector in Vietnam using the FAO categorization, first of all distinguishing between policies supporting production and trade and according to their principal aim (land protection, input cost reduction, irrigation and infrastructure support, price support, and so on), and then focusing on public interventions affecting rice price, both directly (e.g. minimum price) and indirectly (e.g. government procurement). We have collected data and information from a range of sources. The only complete database we found was the FAO's Commodity Policy Developments database, which provides a list of public measures per country and commodity, but the data are of a different nature (floor prices, stocks purchase, subsidies, and so on) and are only available from a January 2011 start date.

We attempted to isolate the effects of public policies on prices, but this proved impossible because of the fragmentary and, in some cases, incomplete nature of available information and data; secondly, domestic prices (see minimum price) are affected by market policies. We were not able to insert more variables relating to other relevant issues into the model, such as reduced water flows and water salinity for the Mekong river, due to the lack of reliable and usable data. ${ }^{44}$

\section{Results}

Since the domestic rice price is naturally influenced by the international market price, it is important to compare the two price series trends (see Figure 2). Specifically, in the reviewed period it can be observed that the domestic price of rice (solid line) falls mostly below the world price (dotted line); this could be partially attributed to the different rice typologies referenced by the international and the domestic prices. Moreover, in relation to the dependence between the price series, the study can 
distinguish different phases. In the first period, up until January 2008, the two series appear to be correlated, and the same pattern occurs starting from January 2014. Between February 2008 and December 2013, the prices show higher volatility and weaker correlation.

The researchers have developed a regression model for the domestic rice price, using as possible covariates:

- at the international level: the price of rice, maize, fertilizer, oil, the USD/Dong exchange rate, and the squared SOI;45

- at the domestic level: rice harvested area, productivity, rice ending stocks, and per capita Gross Domestic Product.

The researchers identified a second order polynomial relationship for the international rice price, and then operated a selection of the other covariates by means of a stepwise forward criterion. The model was estimated through the generalized least squares method, in order to take into account the residuals' heteroskedasticity. The resulting model parameters estimate is listed in Table 2 below, while some other diagnostics for the model are included in the Appendix.

TABLE 2. Results of the Regression Analysis.

Covariates and Regression Coefficient

\begin{tabular}{|l|c|c|c|c|}
\hline & Value & Std.Error & $\mathrm{t}$-value & $\mathrm{p}$-value \\
\hline (Intercept) & $-184,25620$ & 55,28675 & $-3,332737$ & 0,0012 \\
\hline International price & 1,34080 & 0,34321 & 3,906596 & 0,0002 \\
\hline $\begin{array}{l}\text { International price } \\
\text { (squared) }\end{array}$ & $-0,00096$ & 0,00037 & 2,636545 & 0,0095 \\
\hline Exchange rate & 0,00694 & 0,00226 & 3,065743 & 0,0027 \\
\hline SOI & 4,42517 & 1,75067 & 2,527693 & 0,0128 \\
\hline
\end{tabular}

Note: Nr. of observations 128

The model includes as statistically significant covariates: the world price of rice, the US Dollar/Vietnamese Dong exchange rate and the squared SOI, while the other potential covariates have not been included, since they lacked significance. ${ }^{46}$

The non-linear dependence of the domestic USD price from the international USD price takes into account the USD/VND exchange rate. Indeed, if we estimate the model considering the domestic VND price of rice, we identify a linear relationship between the VND domestic price and the USD international price. However, the statistically significant covariates do not change and are, again: the international USD rice price, the USD/VND exchange rate and the SOI. 
FIGURE 3. Real and Fitted Domestic Price of Rice in Vietnam, USD/MT, October 2004-May 2015

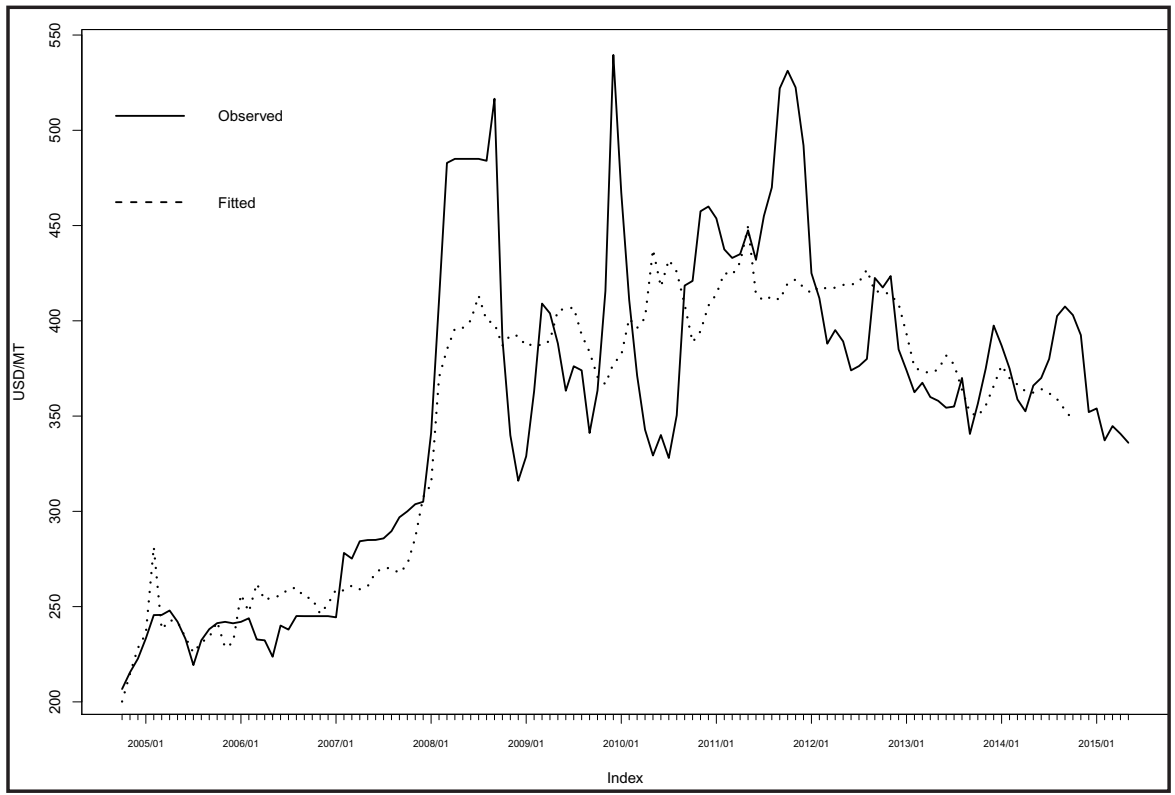

Source: Authors' elaboration based on FPMA, Australian Government National Climate Centre, IMF data.

Figure 3 shows the observed domestic price series (solid line) compared with the fitted values provided by the model (dotted line), while Figure 4 represents the residuals of the model.

The fitted model does not fully explain some of the peaks and lows experienced by the domestic price series, especially in the period between February 2008 and December 2013, where the volatility is higher. The researchers hypothesized that severe weather events, given their unpredictable character and potentially significant impact, might have influenced price variability. They tried to include severe weather events (floods, droughts, storms, typhoons etc.) data in the model, as dummy variables for both the episodes and the economic and human impact measurements (damaged crop areas, amount of economic damage and the size of the affected population). In both cases, they did not find statistically significant evidence of an effect. This lack of significance can be deduced also from Figure 5, where blue vertical lines corresponding to the considered episodes have been added to the series represented in Figure 3. 
FIGURE 4. Residuals of the Model

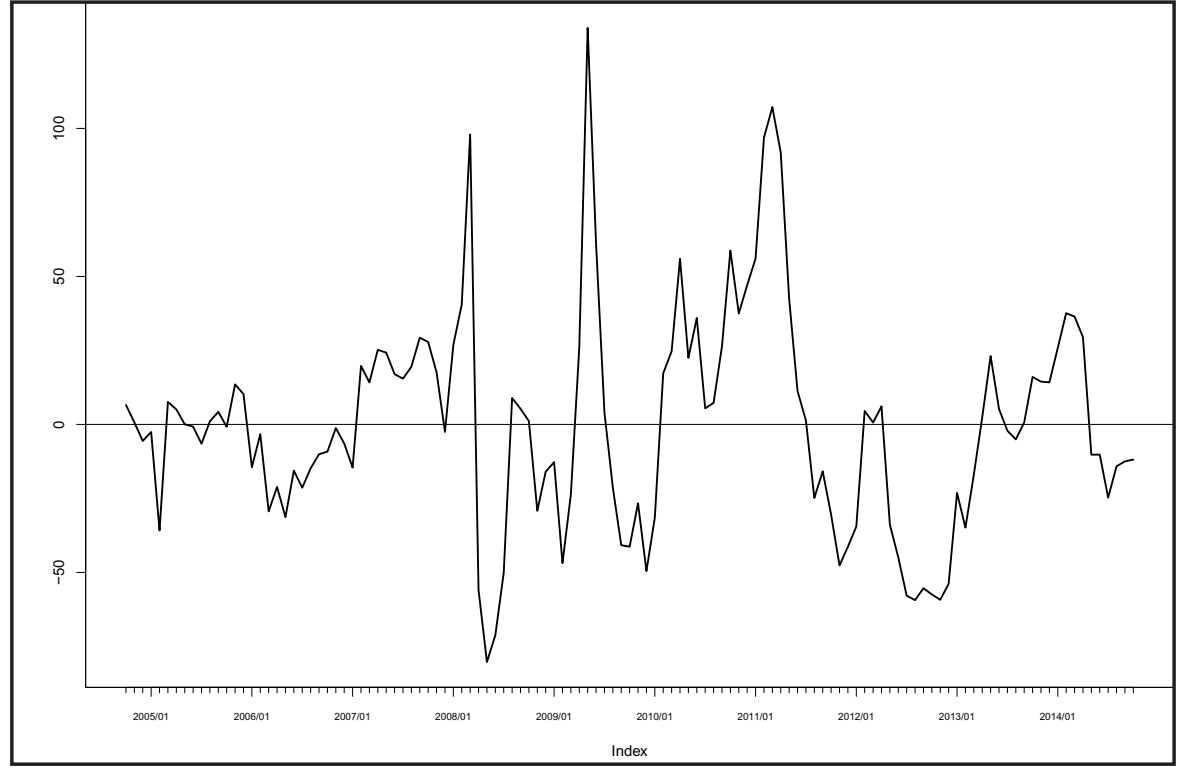

Source: Authors' elaboration based on FPMA, Australian Government National Climate Centre, IMF data.

FIGURE 5. Real and Fitted Domestic Price of Rice in Vietnam and Severe Weather Events, USD/MT, October 2004-May 2015

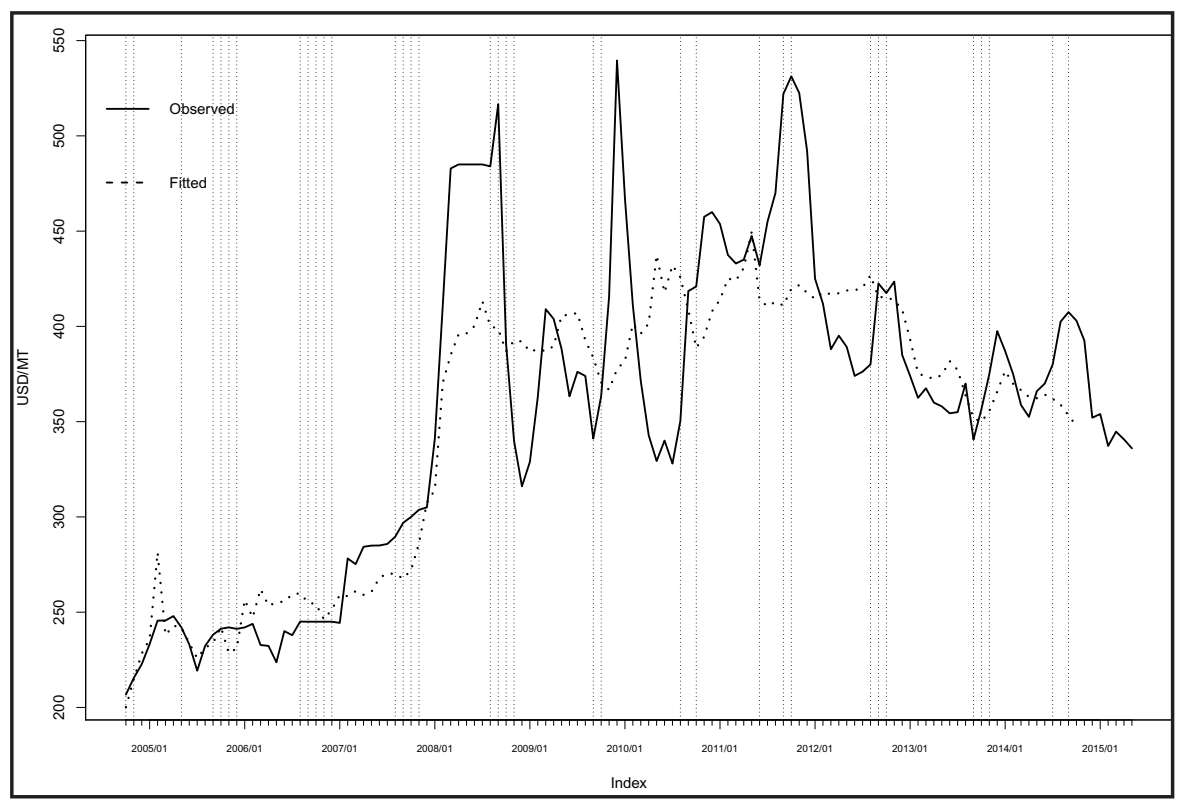

Source: Authors' elaboration based on FPMA, Australian Government National Climate Centre, IMF and CRED data. 
Severe weather events hit Vietnam quite frequently. Furthermore, one can observe a character of seasonality in their occurrence: episodes tend to be concentrated between August and November, corresponding to the summer monsoon season in the Mekong Delta, where the flood season is typically in late September and early October. The occurrence of typhoons is also seasonal; they usually hit the south of the country between October and December.

The occurrence of severe weather events coincides with the rice crop harvesting calendar in the Mekong River Deltas region, where most of Vietnam's rice is produced: rice harvesting in the two main cropping seasons ${ }^{47}$ happens between August and December. At this stage, however, there is no clear evidence of links between severe weather episodes and peaks in the domestic rice price.

\section{Concluding Remarks}

After approximately 30 years of implementing the Doi Moi process, Vietnam is recording a relatively high economic growth rate, despite difficulties deriving from international and local economic volatility. Its integration into ASEAN and the WTO and its economic policy reforms have progressively increased its international integration through trade, investment inflows and labour exports. According to the World Bank income classification, since 1990 Vietnam has moved up more than 50 places, turning from a low-income country into a lower-middle-income country in 2014. Its international economic integration has been strengthened, infrastructures have been improved, and attention has been paid to political and social stability as well as environment protection. The proportion of the population living under the national poverty line and suffering from undernourishment has declined; food availability and national food security were achieved and rural development has progressed, with agricultural exports continuously increasing. Still, despite remarkable progress to-date, Vietnam also faces serious obstacles. The country displays the typical features of a dual economy: on the one hand, most of the population are low-income and live in rural areas; on the other hand, it is a fast-growing economy with increasing industrialization and urbanization. The majority of the Vietnamese population, living in rural areas, have income levels far below middle-income levels; this is driving the movement of the rural population to urban centres.

The country as a whole is a net rice exporter; nevertheless, the vast majority of the population are net buyers of rice, including also house- 
holds in the Mekong and Red River Delta. Moreover, Vietnam is very vulnerable to the impact of climate variability, with climate-related natural disasters that are likely to grow in intensity and frequency; the country has a limited capacity to cope with the adverse impact of severe weather events. In addition to affecting crop location, timing and productivity, such events also affect the stability of food supplies, creating new food security challenges and affecting the quantity of produce available for trade, as well as food prices. In this context, rice assumes strategic relevance.

When conducting the analysis on the domestic price of rice in Vietnam and its main determinants, the researchers encountered several constraints in relation to data availability and reliability. The results of the multiple regression analysis (Table 2) suggest that the main independent variables explaining the pattern of the domestic rice price in Vietnam between October 2004 and May 2015 are, in order of relevance, the international rice price, the exchange rate and the Southern Oscillation Index.

The world price of rice is the most statistically significant variable of all, implying that there is a strong relationship between the international and the domestic rice markets. Exports represent a significant share of rice production in Vietnam, and its position in international trade has been consistently strengthening. In the study model, the influence of public policies was not considered, because of the fragmentary and partially available nature of the data. Nonetheless, we note that public policies could play a role in the domestic market through direct and indirect measures aimed at supporting the various actors in the rice sector: sustaining producers' profits on the one hand, and keeping prices stable and thereby ensuring the continual availability of agricultural resources to consumers on the other. Ultimately, the authorities can do little to influence international prices and exchange rates.

In relation to the effects of climate change, however, a wide range of adaptation and mitigation measures in rice production systems could be introduced. More specifically, adaptation measures would help farmers to better cope with climatic events, while mitigation practices would contribute to the global reduction of GHG emissions from rice production. The climate is expected to become more extreme during seasonal transitions, with extreme weather patterns linked to the transition from the dry season to the rainy season. In particular, rainfall is expected to be even more concentrated in the rainy seasons, leading to an increase in the intensity, frequency and duration of floods. Global warming is forecast to greatly influence the distribution and variability 
of the monsoon rainfall, and increasing intensities of rainfall during the monsoons will be a major cause of flooding.

Research and innovation are required in relation to improved crop varieties resilient to climate change and suited to a variety of ecosystems and farming practices. Agricultural planning, policies and farm practices based on actual knowledge of the systems that are already in place, but with emphasis on new adjustments to make them function with much greater efficiency in the future are necessary. Improved knowledge and technology in relation to the efficient use of inputs would allow farmers to increase their income. Last, but not least, farmer education plays an important role in addressing sustainable livelihoods and in meeting the need to provide food for all.

Carolina Gavagnin is Research Grant Holder at the Department of Economics of $\mathrm{Ca}$ 'Foscari University of Venice. Her research activity focuses on agricultural markets, food security and climate variability. Email: carolina.gavagnin@unive.it

Maria Bruna Zolin is Professor of Economics - Commodity Markets, International Trade of Commodities, Rural Development - at the Department of Economics of $\mathrm{Ca}$ ' Foscari University of Venice. Her research activity focuses on food and energy security, sustainable development, agricultural policies.Email: zolin@unive.it

Andrea Pastore is Professor of Statistics at the Department of Economics of $\mathrm{Ca}$ 'Foscari University of Venice. His research interests include: multivariate statistical analysis, clustering, applications of statistical methods to environmental sciences, marketing, and epidemiology. Email: pastore@unive.it

\section{NOTES}

1 See World Factbook 2014 at https:/ / www.cia.gov/library/publications/resources / the-world-factbook/. Accessed 12 May 2015.

2 Twenty-eight for males and 30 for females.

3 The GDP per capita is 2,032 (USD) in 2014, compared to 1,169 (USD) in 2010 . See Trading Economics 2014. Indicators: GDP per capita. http:/ / www.tradingeconomics.com/. Accessed 3 December 2015.

4 ILO research shows that it will change by 2020 with a forecasted 21.1 million people employed in this sector as the economy "shifts towards higher value-added, and more technology- and capital-intensive industries and service sectors" (ILO 2011: 21). See New report reveals dynamic trends and important emerging issues in Vietnam's labour market at http:/ / www.ilo.org/hanoi/Informationresources/Publicinformation/WCMS_150720/lang-- en/index.htm. Accessed 24 April 2016. In accordance with ASEAN aims, an increase in labour productivity will be fundamental. Although 
labour productivity in Vietnam grew by 4.5 per cent on average, Vietnam's labour productivity is still near the bottom and, at this rate, Vietnam will reach the Philippines labour productivity level by 2038 and Thailand's level by 2069 (ILO 2015). See Why is labour productivity important in economic integration? at http:/ / www.ilo. org/hanoi/Informationresources/Publicinformation/newsitems/WCMS_340867/ lang--en/index.htm. Accessed 24 May 2016.

5 World Bank 2014. Inequality in Vietnam: A Special Focus of the Taking Stock Report July 2014 - Key Findings. World Bank. http:/ / www.worldbank.org/en/news/feature/2014/07/08/inequality-in-vietnam-a-special-focus-of-the-taking-stock-reportjuly-2014. Accessed 2 February 2016.

6 According to FAOSTAT, agricultural land comprises arable land, permanent crops and permanent meadows and pastures. Arable land is defined as land under temporary agricultural crops (multiple-cropped areas are counted only once), temporary meadows for mowing or pasture, land under market and kitchen gardens and land temporarily fallow (less than five years).

7 'Land rights in Vietnam are divided into three categories: land ownership, land management, and land use rights'. See Hansen 2013. Land Law, Land Rights, and Land Reform in Vietnam: A Deeper Look into "Land Grabbing" for Public and Private Development. Independent Study Project (ISP) Collection. Paper 1722. http:/ / digitalcollections.sit.edu/isp_collection/1722. Accessed 13 March 2016.

8 See UNEP and IPONRE 2009. Vietnam Assessment Report on Climate Change. Institute of Strategy and Policy on natural resources and environment and United Nations Environment Programme. Hanoi. http://www.unep.org/pdf/dtie/VTN_ASS_ REP_CC.pdf. Accessed 5 February 2016.

9 See UNFCCC 2010. Vietnam's second national communication to the United Nations Framework Convention on Climate Change. Social Republic of Vietnam Ministry of Natural Resources and Environment. Hanoi. http://unfccc.int/resource/docs/ natc/vnmnc02.pdf. Accessed 14 January 2016.

10 See McSweeney, New, and Lizcano 2012. UNDP Climate Change Country Profile: Vietnam.http://www.geog.ox.ac.uk/research/climate/projects/undp-cp/UNDP_reports/Vietnam/Vietnam.hires.report.pdf. Accessed 3 April 2016.

11 ENSO is a periodic fluctuation of the sea surface temperature (El Niño) and the pressure of the atmosphere (Southern Oscillation) across the equatorial Pacific Ocean.

12 See GFDRR 2011. Vulnerability, Risk Reduction and Adaptation to climate change in Vietnam - Climate Risk and Adaptation Country Profile. Global Facility for Disaster Reduction and Recovery. April 2011. http:/ / sdwebx.worldbank.org/climateportalb/ doc/GFDRRCountryProfiles/wb_gfdrr_climate_change_country_profile_for_VNM. pdf. Accessed 14 March 2016.

13 See Walker and Sydneysmith 2008. From Impacts to Adaptation: Canada in a Changing Climate 2007. Government of Canada. Ottawa. https://www.nrcan.gc.ca/sites/ www.nrcan.gc.ca/files/earthsciences/pdf/assess/2007/pdf/full-complet_e.pdf. Accessed 27 February 2016.

14 Calculation of the SOI: (Standardized Tahiti - Standardized Darwin)/Monthly Standard Deviation.

15 See Kreft and Eckstein 2014. Global climate risk Index 2015. Germanwatch. Berlin. https://germanwatch.org/en/. Accessed 18 June 2016.

16 See Badiani et al. 2013. 2012 Vietnam poverty assessment: well begun, not yet done - Vietnam's remarkable progress on poverty reduction and the emerging challenges. World Bank. Washington DC. http://documents.worldbank.org/curated/ en/2013/08/18124050/2012-vietnam-poverty-assessment-well-begun-not-yet-donevietnams-remarkable-progress-poverty-reduction-emerging-challenges. Accessed 
22 February 2016.

17 UNDP 2015. Financing Viet Nam's response to climate change: Smart Investment for a Sustainable Future. United Nations Development Programme. April 2015. http:// documents.worldbank.org/curated/en/260881468185041568/pdf/96580-WPP149247-PUBLIC-Box391458B-Vietnam-CPEIR-Report-ENG.pdf. Accessed 13 March 2016., and World Bank 2011. Vulnerability, Risk Reduction, and Adaptation to Climate Change: Vietnam. Global Facility for Disaster Reduction and Recovery (GFDRR) and the World Bank Climate Change Team of the Environment Department. The World Bank Group. NW Washington. http:/ / sdwebx.worldbank.org/climateportalb/doc/ GFDRRCountryProfiles/wb_gfdrr_climate_change_country_profile_for_VNM.pdf. Accessed 17 January 2016.

18 See Hai 2012. The Rice Situation in Viet Nam. Asian Development Bank. http:/ / www. adb.org/sites/default/files/ project-document/73083/43430-012-reg-tacr-04.pdf. Accessed 26 February 2016.

19 See Maclean, Hardy, and Hettel 2013. Rice Almanac 4th Edition. International Rice Research Institute. Los Baños. Philippines. http://books.irri.org/9789712203008_ content.pdf. Accessed 24 May 2016.

20 USDA Production, Supply and Distribution (PSD) online database available at https:/ / apps.fas.usda.gov/psdonline/app/index.html\#/app/home (accessed 24 July 2016).

21 Rice references are made in relation to rice paddies, unless otherwise specified.

22 VIETRADE 2013. Strengths of Vietnam's rice industry. Vietnam Trade Promotion Agency. http:/ / www.vietrade.gov.vn/en/index.php?option=com_content\&id=2026: strengths-of-vietnams-rice-industry\&Itemid=232. Accessed 22 April 2016.

23 See Ngan, Pham Hoang, and Dawe 2010. The Vietnamese rice industry during the global food crisis. In The Rice Crisis: Markets, Policies and Food Security. Food and Agriculture Organization: 219-232. http:/ / www.fao.org/3/a-an794e.pdf. Accessed 4 June 2016.

24 See Dawe 2010. Can the next rice crisis be prevented? In The Rice Crisis: Markets, Policies and Food Security. Food and Agriculture Organization: 345-356. http:/ / www. fao.org/3/a-an794e.pdf. Accessed 4 June 2016.

25 See Denning and Tòng Xuân Võ 1994. Vietnam and IRRI: A Partnership in Rice Research. International Rice Research Institute and Ministry of Agriculture and Food Industry. Proceedings of a conference held in Hanoi. 4-7 May 1994. http:/ / books. irri.org/9712200671_content.pdf Accessed 19 January 2016.

26 See Young, Weils, Cramer, and Khiem 2002. Vietnam's rice economy: Developments and prospects. Arkansas Agricultural Experiment Station. University of Arkansas Division of Agriculture. Research Report 968. http:/ / arkansasagnews.uark.edu/968. pdf. Accessed 22 April 2016.

27 The government is very concerned about the food security of the urban poor, and has in the past (in particular in 2007-2009) acted to dampen the tendency towards rice price increases (Timmer 2014).

28 See Cong Thang and Thi Bao 2015. Rice Policy Review in Vietnam. FFTC Agricultural Policy Database. http://ap.fftc.agnet.org/ap_db.php?id=406. Accessed 9 March 2016.

29 USDA 2012. Commodity Intelligence Report. United States Department of Agriculture Foreign Agricultural Service. December 2012. http://www.pecad.fas.usda.gov/ highlights/2012/12/Vietnam/. Accessed 1 December 2015.

30 See Nachmany et al. 2015. The global climate legislation study. A review of climate change legislation in 99 countries. The Grantham Research Institute on Climate Change and the Environment at the London School of Economics. http:/ / www.lse. 
ac.uk/GranthamInstitute/wp-content/uploads/2015/05/Global_climate_legislation_study_20151.pdf. Accessed 13 May 2016.

31 See Childs and Kiawu 2009. Factors Behind the Rise in Global Rice Prices in 2008. Outlook No. RCS-09D-01. United States Department of Agriculture (USDA). http:/ / www.ers. usda.gov/media/257445/rcs09d01_1_.pdf. Accessed 22 January 2016; OECD 2008. Rising food prices: causes and consequences. Organisation for Economic Cooperation and Development. http://www.oecd.org/trade/agricultural-trade/40847088.pdf. Accessed 15 April 2016; and Pandey, Sulser, Rosegrant, and Bhandari 2010. 'Rice Price Crisis: Causes, Impacts, and Solutions'. Asian Journal of Agriculture and Development. 7(2). http://ageconsearch.umn.edu/bitstream/199086/2/AJAD_2010_7_2_1Pandey.pdf. Accessed 1 March 2016.

32 This is the case, for instance, of public policies in the rice sector in Vietnam, climate variability and natural disasters, water salinity.

33 Available at http:/ / agro.gov.vn/news/defaultE.asp,and at http:/ / www.fao.org/ giews/pricetool/ (accessed 30 September 2015).

34 Bangkok is the main location for the export of Thai rice.

35 Available at: http://www.thairiceexporters.or.th/default_eng.htm (accessed 30 September 2015)

36 Available at: http://www.bom.gov.au/climate/ (accessed 20 September 2015).

37 Available at http:/ / www.igc.int/en/Default.aspx (accessed 30 September 2015).

38 The real price of fertilizer is given in constant 2,000 US\$ (with 2010=100). The fertilizer price index includes natural phosphate rock, phosphate, potassium and nitrogenous products.

39 Available at http:/ / data.worldbank.org/ (accessed 20 September 2015).

40 Available at: http:/ / www.imf.org/en/Data (accessed 14 November 2015).

41 Available at http://apps.fas.usda.gov/psdonline/ (accessed 3 September 2015).

42 A wide literature includes inventories among the variables that may - and in many cases do - affect agricultural commodities prices (Frankel and Rose 2009; Tadesse et al. 2016). See also ECB 2011. Economic and Monetary Developments: the External Environment of the Euro Area. European Central Bank Monthly Bulletin. January 2011. https://www.ecb.europa.eu/pub/pdf/mobu/mb201101en.pdf. Accessed 30 May 2016.; and Pietola, Liu, and Robles 2010. Price, inventories, and volatility in the global wheat market. No. 996. International Food Policy Research Institute (IFPRI). http://ebrary.ifpri.org/cdm/ref/collection/p15738coll2/id/2632. Accessed 3 June 2016. Ending stocks summarize the effects of both supply and demand factors and usually are a useful indicator of price movements for commodity markets.

43 See ADB 2012. The Rice Situation in Vietnam. Asian Development Bank, Technical Assistance Consultant's Report, January 2012. https://www.adb.org/sites/default/files/project-document/73083/43430-012-reg-tacr-04.pdf. Accessed 29 May 2016., and WTO 2013. World Trade Report 2013. Factors shaping the future of world trade. World Trade Organization. https:/ / www.wto.org/english/res_e/booksp_e/ world_trade_report13_e.pdf. Accessed 20 January 2016.

44 The only official fact we have found is the following: the size of Area salinized by irrigation in Vietnam in 1999 (Aquastat database).

45 The study takes into account the squared values, since what is of interest is not the sign of the index - whether we are in presence of an El Niño or La Niña episode - but the magnitude of the phenomenon.

46 At the 5 per cent level.

47 Summer-autumn (or early rainy) season and autumn-winter (or late rainy) season. 
Carolina Gavagnin, M. Bruna Zolin and Andrea Pastore

APPENDIX

Table A1. Results

\begin{tabular}{|l|c|c|c|c|}
\hline Coefficient & Value & Std.Error & t-value & $\mathrm{p}$-value \\
\hline (Intercept) & $-184,25620$ & 55,28675 & $-3,332737$ & 0,0012 \\
\hline Inteernational price & 1,34080 & 0,34321 & 3,906596 & 0,0002 \\
\hline $\begin{array}{l}\text { International price } \\
\text { (squared) }\end{array}$ & $-0,00096$ & 0,00037 & 2,636545 & 0,0095 \\
\hline Exchange rate & 0,00694 & 0,00226 & 3,065743 & 0,0027 \\
\hline SOI & 4,42517 & 1,75067 & 2,527693 & 0,0128 \\
\hline
\end{tabular}

\begin{tabular}{|l|c|c|c|c|}
\hline Correlation: & (Intr) & $\begin{array}{c}\text { Internation- } \\
\text { al price }\end{array}$ & $\begin{array}{c}\text { Interna- } \\
\text { tional price } \\
\text { (squared) }\end{array}$ & $\begin{array}{c}\text { Exchange } \\
\text { rate }\end{array}$ \\
\hline International price & $-0,868$ & & & \\
\hline International price (squared) & 0,889 & $-0,994$ & & \\
\hline Exchange rate & 0,189 & $-0,644$ & 0,587 & 0,0075 \\
\hline SOI & 0,106 & $-0,210$ & 0,191 & 0,228 \\
\hline
\end{tabular}

\begin{tabular}{|c|c|c|c|c|}
\hline \multicolumn{5}{|l|}{ Standardized residuals: } \\
\hline Min & Q1 & Med & Q3 & Max \\
\hline$-2,0813000$ & $-0,6521596$ & 0,0018094 & 0,5837314 & 3,3707158 \\
\hline
\end{tabular}

Residual standard error: 1,598542

Degrees of freedom: 121 total; 116 residual

TABLE A2. Severe Weather Events in Vietnam: Location, Type of Event and Impacts, October 2004-May 2015

\begin{tabular}{|l|l|c|c|c|c|}
\hline Date & Location & $\begin{array}{c}\text { Type of } \\
\text { Event }\end{array}$ & $\begin{array}{c}\text { Total } \\
\text { deaths }\end{array}$ & $\begin{array}{c}\text { Popula- } \\
\text { tion } \\
\text { affected }\end{array}$ & $\begin{array}{c}\text { Damage } \\
\text { (000 US\$) }\end{array}$ \\
\hline October 2004 & Mekong River Delta & Flood & 34 & 30,000 & \\
\hline November 2004 & North- and South-Central Coast & Storm & 56 & 500,000 & 23,000 \\
\hline May 2005 & Mekong River Delta & Flood & & 593 & \\
\hline September 2005 & Mekong River Delta & Flood & 39 & 30,000 & \\
\hline September 2005 & $\begin{array}{l}\text { North East, North Central } \\
\text { Coast, North West, Red River } \\
\text { Delta, South Central Coast }\end{array}$ & Storm & 83 & 345,160 & 239,250 \\
\hline October 2005 & $\begin{array}{l}\text { North- and South- Central } \\
\text { Coast, Central Highlands }\end{array}$ & Flood & 84 & 43,800 & 27,000 \\
\hline November 2005 & $\begin{array}{l}\text { South Central Coast, North } \\
\text { Central Coast }\end{array}$ & Storm & 20 & 15,000 & 11,000 \\
\hline December 2005 & $\begin{array}{l}\text { South Central Coast, Central } \\
\text { Highlands, South East, Central } \\
\text { Highlands }\end{array}$ & Flood & 69 & 18,000 & 27,000 \\
\hline
\end{tabular}




\begin{tabular}{|c|c|c|c|c|c|}
\hline August 2006 & North Central Coast, & Flood & 42 & 50,020 & 8,000 \\
\hline \begin{tabular}{|l} 
September-October \\
2006
\end{tabular} & $\begin{array}{l}\text { North Central Coast, South } \\
\text { Central Coast }\end{array}$ & Storm & 71 & $1,467,925$ & 624,000 \\
\hline November 2006 & Northeast & Storm & 13 & & 10,000 \\
\hline December 2006 & \begin{tabular}{|l|} 
South East, Mekong River \\
Delta, South Central Coast
\end{tabular} & Storm & 95 & $1,226,360$ & 456,000 \\
\hline August 2007 & $\begin{array}{l}\text { Central Highlands, North } \\
\text { Central Coast }\end{array}$ & Flood & 74 & 416,130 & 130,000 \\
\hline $\begin{array}{l}\text { September-October } \\
2007\end{array}$ & $\begin{array}{l}\text { North Central Coast, South } \\
\text { Central Coast, North West, } \\
\text { Red River Delta, Mekong River } \\
\text { Delta, North East }\end{array}$ & Storm & 96 & 685,430 & 191,000 \\
\hline \begin{tabular}{|l|} 
October-November \\
2007
\end{tabular} & $\begin{array}{l}\text { North Central Coast, South } \\
\text { Central Coast }\end{array}$ & Flood & 83 & 94,042 & 300,000 \\
\hline \begin{tabular}{|l|} 
October-November \\
2007 \\
\end{tabular} & Mekong River Delta & Flood & 3 & 280,000 & \\
\hline November 2007 & $\begin{array}{l}\text { South Central Coast, North } \\
\text { Central Coast }\end{array}$ & Flood & 55 & 150,000 & 350,000 \\
\hline \begin{tabular}{|l|} 
August 2008 \\
\end{tabular} & North East, North West & Storm & 162 & 57,630 & 120,000 \\
\hline September 2008 & $\begin{array}{l}\text { North East, North West, Red } \\
\text { River Delta, North Central } \\
\text { Coast }\end{array}$ & Storm & 64 & 90,191 & 69,500 \\
\hline $\begin{array}{l}\text { October-November } \\
2008\end{array}$ & $\begin{array}{l}\text { North East, Red River Delta, } \\
\text { North West, North Central } \\
\text { Coast }\end{array}$ & Flood & 99 & 600,000 & 479,000 \\
\hline September 2009 & $\begin{array}{l}\text { Central Highlands, North and } \\
\text { South Central Coast }\end{array}$ & Storm & 182 & $2,477,315$ & 785,000 \\
\hline October 2009 & South Central Coast & Storm & 124 & 500,145 & 280,000 \\
\hline August 2010 & North Central Coast & Storm & 14 & 20,700 & 44,000 \\
\hline October 2010 & North Central Coast & Flood & 105 & $1,440,825$ & 296,500 \\
\hline October 2010 & $\begin{array}{l}\text { South Central Coast, Central } \\
\text { Highlands }\end{array}$ & Flood & 31 & 39,008 & 107,700 \\
\hline September 2011 & North East & Flood & 24 & 300,000 & 44,000 \\
\hline \begin{tabular}{|l|} 
September-October \\
2011
\end{tabular} & Mekong River Delta & Flood & 85 & 600,000 & 175,002 \\
\hline October 2011 & North and South Central Coast & Flood & 13 & 461,584 & \\
\hline \begin{tabular}{|l|} 
August 2012 \\
\end{tabular} & North East, Red River Delta & Storm & 17 & 60,479 & 6,800 \\
\hline September 2012 & $\begin{array}{l}\text { North Central Coast, Red River } \\
\text { Delta }\end{array}$ & Flood & 34 & 17,540 & 30,000 \\
\hline October 2012 & $\begin{array}{l}\text { North Central Coast, Red River } \\
\text { Delta }\end{array}$ & Storm & 11 & 278,490 & 336,000 \\
\hline September 2013 & North Central Coast & Storm & 36 & $1,835,585$ & 663,230 \\
\hline October 2013 & North and South Central Coast & Storm & 20 & 109,754 & 76,000 \\
\hline November 2013 & $\begin{array}{l}\text { North and South Central Coast, } \\
\text { North East, Red River Delta }\end{array}$ & Storm & 16 & 13,094 & 734,000 \\
\hline November 2013 & $\begin{array}{l}\text { South Central Coast, Central } \\
\text { Highlands }\end{array}$ & Flood & 47 & $2,130,001$ & 72,000 \\
\hline July 2014 & North Central Coast & Storm & 27 & 36,000 & 5,925 \\
\hline September 2014 & South Central Coast & Storm & 11 & 11,325 & 4,500 \\
\hline
\end{tabular}

Source: Authors' elaboration based on CRED data 


\section{REFERENCES}

Abbott P.C., Hurt C. and Tyner W.E. 2008. 'What's Driving Food Prices?' Farm Foundation Issue Report. July 2008.

Arezki R. et al. 2014. 'Commodity prices and exchange rate volatility: Lessons from South Africa's capital account liberalization'. Emerging Markets Review. 19: 96-105.

Baffes J. and Dennis A. 2013. 'Long-Term Drivers of Food Prices'. World Bank Policy Research Working Paper. No. 6455. May 12013.

Boo N.V. and Buu B.C. 2010. 'Rice production in Vietnam: Achievements, Opportunities and Challenges'. In B.B. Bong et al. (eds.) Vietnam fifty years of rice research and development: 19-379. Ministry of Agriculture and Rural Development (MARD). Vietnam.

Cosslett T.L. and Cosslett P.D. 2014. 'Water Resources and Food Security in the Vietnam Mekong Delta'. Natural Resource Management and Policy. 44.

Frankel J.A. and Rose A.K. 2010. 'Determinants of Agricultural and Mineral Commodity Prices'. HKS Faculty Research Working Paper Series RWP10-038. John F. Kennedy School of Government. Harvard University.

Ghosh M. and Whalley J. 2004. 'Are price controls necessarily bad? The case of rice in Vietnam'. Journal of Development Economics. 73: 215-232.

Gilbert C.L. 1989. 'The impact of exchange rates and developing country debt on commodity prices'. The Economic Journal. 99(397): 773-784.

Hai N.M. and Talbot T. 2015. 'The political economy of food price policy in Vietnam'. In P. Pinstrup-Andersen (ed.) Food price policy in an era of market instability: a political economy analysis: 319-338. United Nations University - World Institute for Development Economics Research (UNU-WIDER).

Harri A., Nalley L. and Hudson D. 2009. 'The Relationship between Oil, Exchange Rates, and Commodity Prices'. Journal of Agricultural and Applied Economics. 41 (2): 501-510.

Huang B. and Hu Z.Z. 2007. 'The predictive skill and the most predictable pattern in the tropical Atlantic: The effect of ENSO'. Monthly weather review. 135(5): 1786-1806.

Loo Y.Y., Billa L., and Singh A. 2015. 'Effect of Climate Change on Seasonal Monsoon in Asia and Its Impact on the Variability of Monsoon Rainfall in Southeast Asia'. Geoscience Frontiers. 6(6): 817-823.

Naylor R.L. et al. 2007. 'Assessing risks of climate variability and climate change for Indonesian rice agriculture'. Proceedings of the National Academy of Sciences. 104(19): 7752-7757.

Pingali P.L. and Xuan V.T. 1992. 'Vietnam: decollectivization and rice productivity growth'. Economic Development and Cultural Change. 40(4): 697-718.

Rasmusson E.M. and Wallace J.M. 1983. 'Meteorological Aspects of the El Niño/Southern Oscillation'. Science. 222(4629): 1195-1202.

Roberts M.J. et al. 2009. 'Impact of resolution on the tropical Pacific circulation in a matrix of coupled models'. Journal of Climate. 22(10): 2541-2556.

Ropelewski C.F. and Halpert M.S. 1989. 'Precipitation patterns associated with the high index phase of the Southern Oscillation'. Journal of Climate. 2(3): 268-284.

Son D.K. 2010. 'Management policy on Vietnam rice development and trade'. In B.B. Bong et al. (eds.) Vietnam fifty years of rice research and development: 45-56. Ministry of Agriculture and Rural Development (MARD). Vietnam.

St John R.B. 2006. 'Revolution, Reform and Regionalism in Southeast Asia: Cambodia, Laos and Vietnam'. Routledge Contemporary Southeast Asia Series 8. New York: Routledge.

Tadesse G., Algieri A., Kalkuhl M. and von Braun J. 2016. 'Drivers and triggers of international food price spikes and volatility'. In M. Kalkuhl et al. (eds.) Food Price Volatility and Its Implications for Food Security and Policy. Springer International 
Publishing: 59-82.

Timmer C.P. 2014. 'Food security in Asia and the Pacific: the rapidly changing role of rice'. Asia \& the Pacific Policy Studies. 1(1): 73-90.

Tulasombat S., Bunchapattanasakda C. and Ratanakomut S. 2015. 'The Effect of Exchange Rates on Agricultural Goods for Export: A Case of Thailand'. Information Management and Business Review. 7(1): 1-11.

Van Suu N. 2007. 'Contending views and conflicts over land in Vietnam's Red River Delta'. Journal of Southeast Asian Studies. 38(2): 309-334.

Van Suu N. 2009. 'Agricultural land conversion and its effects on farmers in contemporary Vietnam'. European Journal of Anthropology. 2009(54): 106-113.

Vu M.T., Raghavan S.V., Pham D.M. and Liong S.Y. 2015. 'Investigating drought over the Central Highland, Vietnam, using regional climate models'. Journal of Hydrology. 526: 265-273.

Xie S. and Napasintuwong O. 2014. 'Review of rice policies in China, Thailand and Vietnam'. Agricultural and Resource Economics (ARE). Working Paper 2557/1. Bangkok. March 2014. 